\title{
A techno-economic analysis of floating photovoltaic systems, for southern European countries
}

\author{
J. Baptista ${ }^{1,2}$, P. Vargas $^{1}$ and J. R. Ferreira ${ }^{3}$ \\ ${ }^{1}$ Department of Engineering \\ ${ }^{2}$ CPES -INESCTEC UTAD Pole \\ University of Trás-os-Montes and Alto Douro \\ Quinta de Prados - Vila Real, 5001-801 Vila Real, Portugal \\ baptista@utad.pt, al70216@alunos.utad.pt \\ ${ }^{3}$ Department of Electrical and Computer Engineering \\ FEUP - Rua Dr. Roberto Frias, s/n, 4200-465 Porto, Portugal \\ jrf@fe.up.pt
}

\begin{abstract}
In the last few decades, the vast majority of world states have faced increased energy consumption using more environmentally friendly production technologies. The use of traditional renewable energies like hydro, wind and solar has been the solution found. Despite this, new technical solutions and strategies are beginning to emerge, of which Floating Solar Photovoltaic (FSPV) systems are part. In this framework, southern European countries have excellent climate conditions for reinforcing the use of solar energy. This research assess the existing Portuguese potential for floating PV systems and its integration in the power grid. A floating solar power plant of $1 \mathrm{MW}$ in Gouvães dam included in the Tâmega hydroelectric complex, under construction in northern Portugal was sizing and evaluated its energy potential. A techno-economic feasibility study was also carried out taking into account the current investment costs and energy tariffs in the Iberian liberalized market. This integrated analysis allowed to obtain important results on the current state of the art, types of technologies available, their costs and the payback period for this type of projects.
\end{abstract}

Key words. Renewable energy, floating photovoltaic system, solar power plants, techno-economic feasibility.

\section{Introduction}

The Portuguese Roadmap for Carbon Neutrality 2050 (RNC2050) was developed in line with the territorial dimension included in the National Spatial Planning Policy Program and incorporating the orientations of the Circular Economy Action Plan. This is an important document that deserves to be highlighted and where civil society played a fundamental role, having participated in all phases of its elaboration, which allowed a wide national discussion on the issues. Accomplishing carbon neutrality in Portugal by 2050 implies reducing greenhouse gas emissions by more than $85 \%$, compared to 2005 , and ensuring an agricultural and forestry carbon sequestration capacity of around 13 million tonnes. [1]. To achieve these goals, it is necessary to increase the efficiency of the energy system, reducing primary energy consumption and increasing renewable resources in final energy consumption. In recent years the country has been making a strong bet in the use of its endogenous resources, with emphasis on onshore wind power and hydropower. From now, there is a need for investments to go to other emerging areas, such as offshore wind energy and solar energy, as that the country has excellent conditions to grow in these two areas. In this context, the use of solar energy from floating systems is another interesting option that deserves to be explored. Despite the growth of the last few years, the capacity of solar power production in Portugal is still reduced when compared to other renewable sources, such as hydroelectric and wind power. Therefore, in the short term, new bets on solar energy are expected, with Floating Solar Photovoltaic (FSPV) systems playing an important role, helping to achieving the 2030 targets.

FSPV systems represent an emerging opportunity in which PV systems are sited directly on water bodies, such as dams, lakes, ponds, quarries lakes or reservoirs. The study of FSPV systems has been addressed by several authors in recent years. Many of these studies give priority to review the state of the art, framing this type of renewable solution [2]-[4]. Other researches addresses issues related to energy assessment, verifying the economic feasibility of the investments [5]-[8]. In [9] an extensive field measurement data are presented that allow comparing the performance of PV systems installed in different environments, such as in the water and on the roof. The performance of different FSPV systems is also analyzed, concluding that FSPV have some performance benefits. In [10] the analysis of the performance of different FSPV design solutions is performed and discussed. The results of experimental tests show a considerable increase in efficiency due to the positive tracking and cooling effects. Gains due to the use of flat reflectors are also analyzed. Sizing, planning, construction process and the technologies involved are also an area that has deserved the interest of researchers, like [11]-[13]. 
The main aim of this paper is to evaluate the Portuguese potential for this kind of systems and sizing and assesses the energy potential of a plant of $1 \mathrm{MWp}$, located in Gouvães dam, that is included in the Tâmega hydroelectric complex under construction in northern of Portugal. This paper extends the study presented by the authors in [14]. A detailed model of PV systems and a depth techno-economic feasibility analysis was carried out. Several financial parameters were calculated such as the Payback period, Net Present Value, Internal Rate of Return, among others.

The paper is organized as follow: Section 2 gives an overview about the potential of floating PV systems and addresses the technologies, section 3 addresses the Portuguese case and the optimal conditions for this type of facilities, section 4 presents the PV systems modelling, section 5 shows the results of a case study, carrying out a techno-economic feasibility analysis, and finally section 6 draws the main conclusions.

\section{Floating Systems Potential Overview}

Based on available surface area of artificial water bodies worldwide and system assumptions, the World Bank and the Solar Energy Research Institute of Singapore (SERIS) estimate global technical potential of FSPV may range from $400 \mathrm{GW}$ to $1000 \mathrm{GW}$. Global installed capacity has grown from approximately $10 \mathrm{MW}$ in 2014 to near $1100 \mathrm{MW}$ by mid-2018. In recent years the installed power has grown abruptly, as shown in Fig. 1 [15]. There are several advantages to mounting PV panels on water rather than on land:

-Eliminates the problem of landlessness. One of the biggest advantages of FSPV is that the installations do not require valuable land space;

-The levels of solar radiation are higher and without shadows;

-Cooling systems of PV panel, which increases electricity production by up to $15 \%$ [5];

-The floating solar structure can reduce evaporation by $50 \%$ to $80 \%$ [16];

-There is no need to invest in the preparation of the floor; - Operation and maintenance cost is comparatively less compared with land-based systems as water for cleaning is available at source and components were less likely to overheat [17].

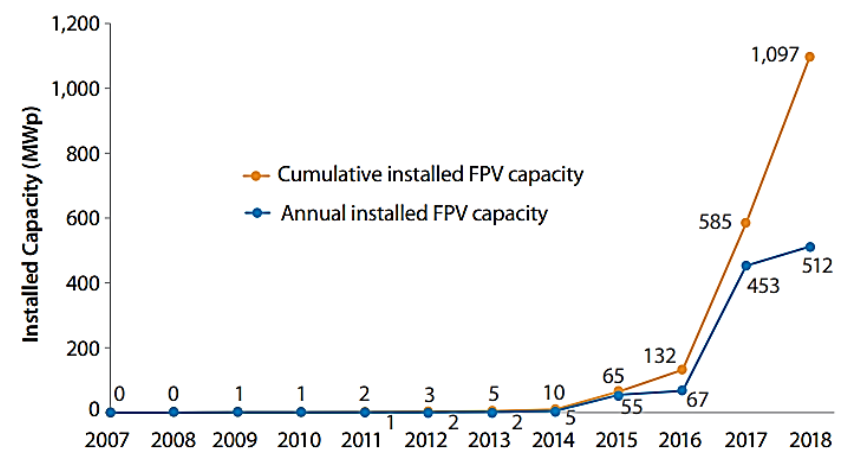

Fig.1. Global installed capacity of Floating Solar PV systems worldwide in MW.

\section{The Portuguese Case}

In Portugal, there are about 250 large dams with a height of over 15 meters and storage of over $1 \mathrm{hm}^{3}$ (1 million cubic meters) [18]. Some of these dams were built to create water storage facilities that would in some cases provide irrigation water supplies and in others, public supply, particularly in the most irregular regions, in the south of the country and inland. In the north of the country, where resources are more abundant and regular, hydroelectric facilities have been built, both for flow river regularization, water storage and electricity production. One of the largest FSPV projects in Europe is currently underway in Alqueva dam, with the installation of 10 selfconsumption production units next to several pumping stations. This project comprises the installations of 10 floating PV power plants with a total installed capacity of $50 \mathrm{MWp}$.

Taking into account the solar resource, Portugal belongs to the group of European countries that present the best levels of annual solar radiation. This means a huge advantage for the country, as electricity produced in Portugal can cost less than that produced in most other states. Solar radiation levels increases from north to south, due to the influence of latitude on the height of the Sun, and from the coast to the interiors, due to the decrease in cloud cover. In Portugal, the abundance of solar resources is excellent, in comparison with other countries of European Union (EU).

According the Portuguese national plan for energy and climate [19], the dam reservoirs in Portugal will have new rules in order to encourage the increase of floating solar power plants. It is predicted that if $20 \%$ of the area of the 50 largest reservoirs is used to produce electricity from PV systems, therefore, Portugal could reach the target of 7 GW of renewable energy needed to meet the decarbonisation goals. The introduction of FSPV systems with installed capacities of up to $50 \%$ of the original transformer capacity does not significantly interfere in the hydro power generation.

According [20], the economically viable floating PV potential in the reservoirs of electro producing dams in Portugal, with shared electrical infrastructure, was evaluated at $2.55 \mathrm{GW}$. Therefore, it can be concluded, that the FSPV systems has the potential to contribute significantly to the national PV capacity in short-term.

The first Portuguese FSPV project, started operating in 2016 and is located in the Alto Rabagão dam reservoir, in the northern region of the country. This project consists of $840 \mathrm{PV}$ panels, which occupy an area of $2500 \mathrm{~m}^{2}$, have an installed capacity of approximately $220 \mathrm{kWp}$ and an estimated annual production of around $300 \mathrm{MWh}$. At the end of 2019, EDIA (Alqueva Development and Infrastructure Company) completed the construction of two FSPV of $1 \mathrm{MW}$ each for self-consumption at the Lage and Cuba-Este pumping stations, near Alqueva hydro power plant. The production of these units will be largely absorbed by the pumping units installed there. Each system is composed by $3024 \mathrm{PV}$ panels, occupying an area of approximately 1 hectare over the water of the Alqueva reservoir (Fig. 2). This project continues to grow, with the expected increase in installed capacity in floating systems for the next few years in the Alqueva reservoir, expected 
to be the largest floating PV solar project in Europe. This project comprises the installations of 10 floating PV power plants with a total installed capacity of $50 \mathrm{MWp}$ and will occupy an area of about 50 hectares over water. With an estimated production of $90 \mathrm{GWh} /$ year, the energy obtained from all these PV plants would be enough to supply about $2 / 3$ of entire population of Baixo Alentejo region.

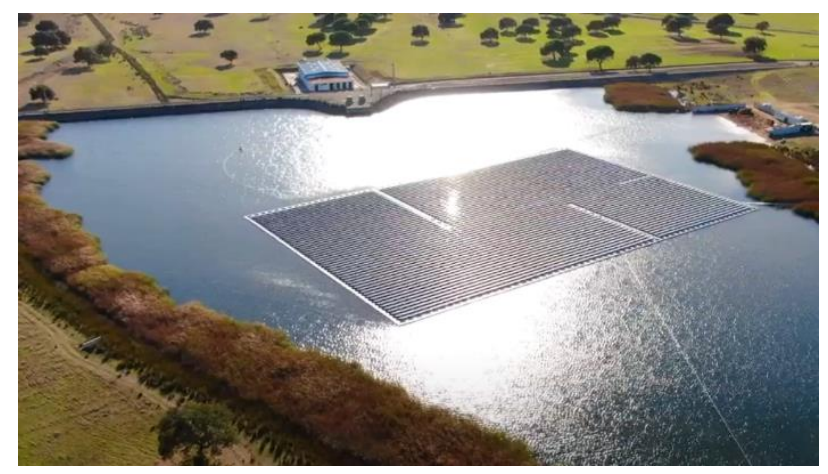

Fig.2. Cuba-Alqueva 1MWp FSPV system.

\section{Systems Modelling}

This section describes the theoretical model used for sizing a grid-connected PV system and for further annual electricity production calculation. Therefore, these calculations are the basis of the developed study.

Usually the PV cell is approached by a current source in parallel with a diode, where the output being proportional to solar radiation, as shown in Fig. 3. The current source represents the equivalent current generated by solar radiation and the diode representing the electron exchange at a p-n junction crossing by ID current, which is dependent on its own saturation current and voltage between the PV cell connections, given by (1).

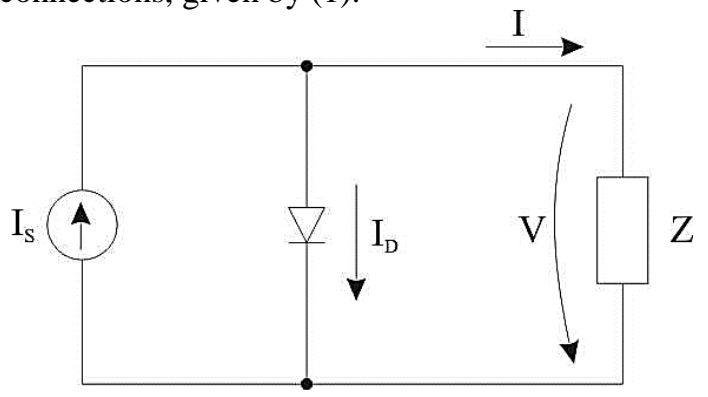

Fig.3. Equivalent electrical circuit for a PV cell.

$$
I_{D}=I_{0}\left(e^{\frac{V}{m V_{T}}}-1\right)
$$

Where $m$ is the diode ideality factor and $V_{T}$ is the thermal potential. Applying Kirchhoff's current law to the circuit, the load current is given by (2).

$$
I=I_{S}-I_{D}=I_{S}-I_{0}\left(e^{\frac{V}{m V_{T}}}-1\right)
$$

For short-circuit conditions, $I_{S}=I_{S C}$, this is the maximum value that the load current can reach. This value is a cell characteristic and is provided by the manufacturer, obtained in Standard Test Conditions-STC $\left(1000 \mathrm{~W} / \mathrm{m}^{2}\right.$ of incident radiation and $25^{\circ} \mathrm{C}$ for cell temperature). At open circuit conditions, $I=0$ and $V=V_{O C}$, resulting in a reverse saturation current in STC conditions given by (3).

$$
I_{0}=\frac{I_{S C}}{e^{\frac{V_{O C}}{m V_{T}}}-1}
$$

The typical open circuit voltage $\left(V_{O C}\right)$ is about $0.6 \mathrm{~V}$ for a crystalline solar cell and it is relatively independent of the solar irradiation. The current produced by the cell depends mainly on the irradiation, ambient temperature, surface area of the cell, and the voltage at which it is operating. The maximum power of a cell does not exceed $2 \mathrm{~W}$, which is insufficient to supply most applications, so the cells are grouped into PV modules, which, in turn, are also grouped together, forming a PV panel. The parameters that characterize PV modules are usually:

- Constant parameters, like the ideality factor $(m)$ given by (5).

$$
m=\frac{V_{\max }-V_{O C}}{V_{T} \times \ln \left(1-\frac{I_{\max }}{I_{S C}}\right)}
$$

-Parameters that depend on radiation, like short-circuit current $\left(I_{S C}\right)$, given by $(6)$, where $G$ represents the solar radiation.

$$
I_{\max }=I_{S C}^{S T C} \frac{G}{G^{S T C}}
$$

-Parameters that depend on temperature like reversed current, given by (7) and the maximum voltage $\left(V_{\max }\right)$, given by (8).

$$
\begin{gathered}
I_{0}=I_{0}^{S T C} \frac{T}{T^{S T C}} e^{\frac{\epsilon}{m^{\prime}}\left(\frac{1}{V_{T}^{S T C}}-\frac{1}{V_{T}}\right)} \\
V_{\max }=m V_{T} \ln \left[\frac{\left(I_{S C}^{S T C}-I_{\max }^{S T C} \frac{G}{G^{r}}\right.}{I_{O}^{S T C}\left(\frac{T}{T^{S T C}}\right)^{3} e^{\frac{\epsilon}{m^{\prime}}\left(\frac{1}{V_{T}^{S T C}}-\frac{1}{V_{T}}\right)}}\right]
\end{gathered}
$$

Therefore, the maximum power extracted from a panel can be obtain by (9).

$$
P_{\max }=V_{\max } \cdot I_{\max }
$$

Considering the use of an inverter to generate a sinusoidal waveform at the output, the energy produced by a panel during a given time interval $\Delta t$ can then be calculated from (10). Where $\eta_{i n v}$ is the inverter efficiency.

$$
E=\eta_{i n v} \sum_{i=1}^{n} P_{\max }(G, T) \cdot \Delta t_{i}
$$

\section{Case Study}

In this section a case study will be presented which has as main aim to sizing and evaluate the technical and economic conditions of a FSPV system that may be installed in the Gouvães dam reservoir currently under construction on the Tâmega River. 


\section{A. Energy Balance}

With $154 \mathrm{~km}$ in length the Tâmega River is one of the international tributaries of the Douro River. It is born in Spain, in the Sierra de San Mamede, Galicia, and flows into Entre-os-Rios (near Porto). The first objective is to sizing a floating PV Power plant, with $1 \mathrm{MWp}$, in one of the three dams under construction on the Tâmega River, considering solar radiation data and climate specificities in the region. The Gouvães dam is located in the municipalities of Vila Pouca de Aguiar and Ribeira de Pena with the coordinates (41 ${ }^{\circ} 29^{\prime} 32.2^{\prime \prime N}$; 743'34.0"W). Fig. 4 shows the location map. To obtain the energy balance of a grid-connected PV system it is fundamental to know the local climate data, namely the radiation and the ambient temperature. To carry out this study these data showed in Fig. 5, was obtained from European Commission PVGIS Database [21].

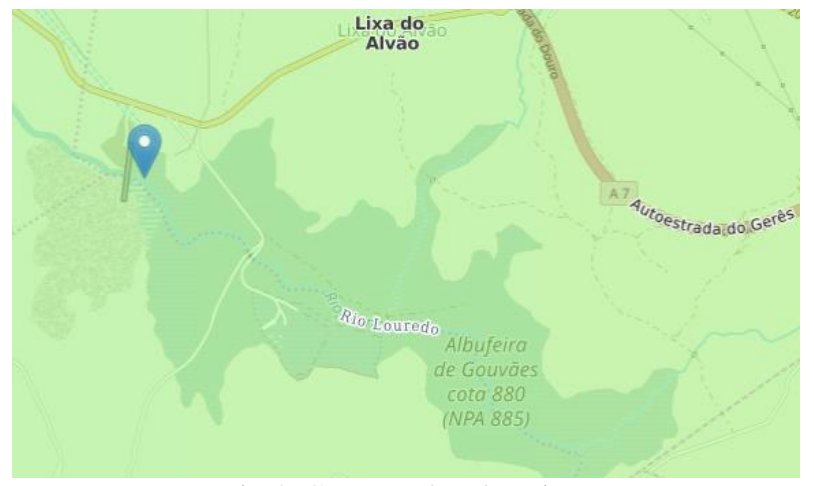

Fig.4. Gouvães dam location.

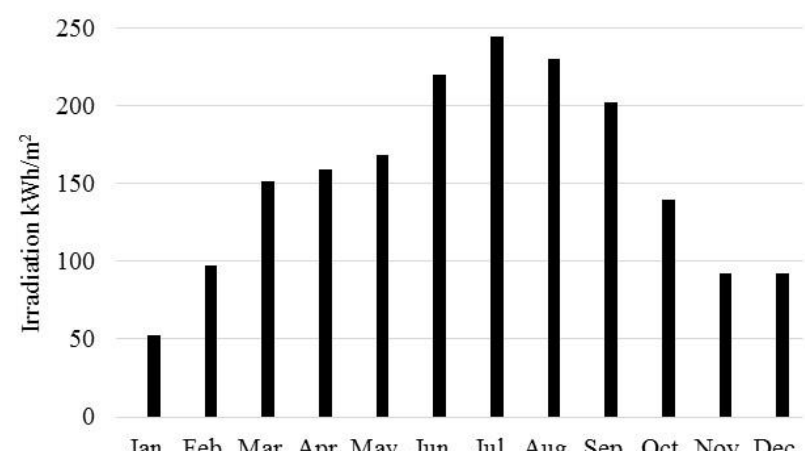

(a)

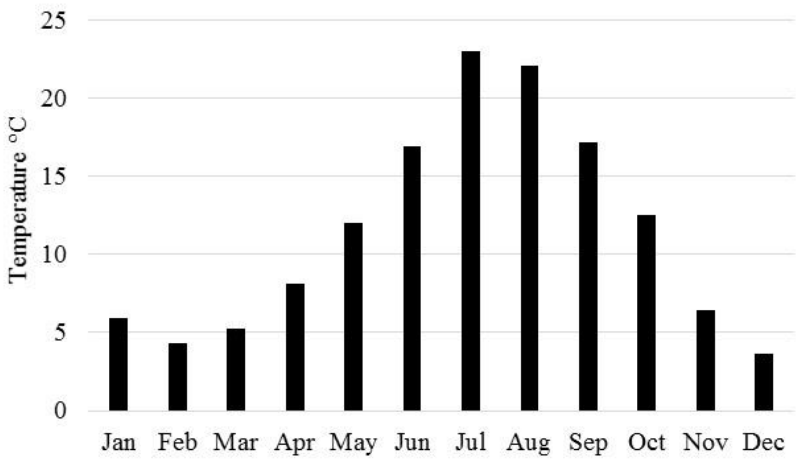

(b)

Fig.5. Climate data at Gouvães dam location. (a) Irradiation at optimal angle, (b) Monthly average temperature.

After consulting several manufactures, the PV solar panel chosen for the PV system is the Panasonic N340, which presents a good performance.
Based on $1 \mathrm{MWp}$ power previously defined for the system, and take into account the maximum power of the chosen panel $(340 \mathrm{~W})$ the total number of panels needed will be 2941, given by (11). For reasons of good practice, 3000 panels were chosen resulting in a total installed power of 1,02 MWp.

$$
N_{\text {panels }}=\frac{P_{\text {rated }}}{P_{\text {panel }}}=\frac{1000000}{340}=2941
$$

The PV panels are placed in strings, on the floating platform, fixed to the bottom of the dam, allowing smooth oscillations with the variations of the water level. The chosen technology, made in Portugal, developed by the company Solar Float and Simoldes, which are developing projects FSPV power plants in Alqueva.

Before defining the number of strings needed and the number of panels in each string, it was necessary to define the DC/AC inverter to be used in the system. In that case the option was the Sunny Tripower 2500TL, used in several solar power plant projects in Portugal. Considering the technical specifications of the inverter, the number of panels in each string is calculated by (12).

$$
N P_{\text {string }}=\frac{V_{\text {Max.inverter }}}{V_{\text {Max.panel }}}=\frac{600}{59.7}=10
$$

Once the number of panels per string is already defined, it is necessary to know the number of strings needed through (13).

$$
N_{\text {strings }}=\frac{N_{\text {panels }}}{N P_{\text {string }}}=\frac{3000}{10}=300
$$

In that case 300 strings are needed. Take into account that each inverter has 2 MPP and that each MPP can have a maximum of 3 strings, it gives a maximum of 6 strings per inverter. In order to distribute all the 300 strings across the inverters, the final distribution will need 50 inverters.

The forecast of the monthly energy produced over a year, taking into account the local climate conditions was calculated on a spreadsheet based on the concepts covered in [22] and explained in the previous section. The results are shown in the graph in Fig. 6, where it appears that energy production follows the curve of solar radiation. The estimation of annual electricity production reaches an accumulated value of approximately $1.8 \mathrm{GWh}$.

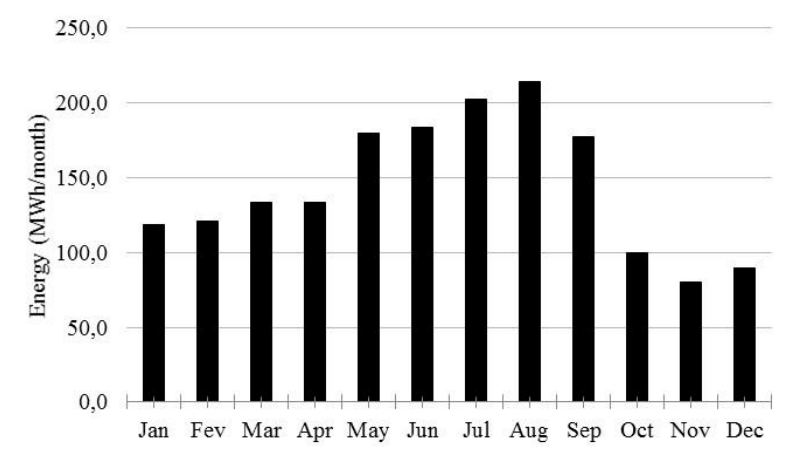

Fig.6. Monthly energy production.

\section{B. Economic Analysis}

In order to find out if the project is profitable, it is necessary to make its economic evaluation. The evaluation 
criteria that are commonly used to measure the economic interest of renewable energy projects may appear to be entirely objective, which is not always true due to the uncertainty. The main economic indicators used to evaluate this kind of project investment are the Net Present Value $(N P V)$, the Internal Rate of Return (IRR) and the Payback period $(P b)$. The $N P V$ is the difference between cash inflows and outflows, called cash flows, updated over the project lifetime. If $N P V>0$ the investment would add value and may be accepted, by other hand if $N P V<0$ the investment would subtract value and the project may be rejected. The $I R R$ is a measure of an investment's expected future rate of return and must show higher values than interest rates. The $P b$ period refers to the amount of time it takes to recover the cost of an investment, therefore shorter paybacks mean more attractive investments. The equations of $N P V, I R R$ and Payback can be expressed, respectively, as in (14), (15) and (16):

$$
N P V=\sum_{j=1}^{n} \frac{R_{l j}}{(1+i)^{j}}-I_{t}+\frac{V_{R}}{(1+i)^{n}}
$$

Where $R_{l j}$ is the net cash flow for year $j, n$ is the project lifetime, $I_{t}$ is the initial investment (Capital Expenditure CAPEX), $i(\%)$ is the discount rate and $V_{R}$ represents the plant residual value at the end of the lifetime.

$$
\begin{gathered}
\sum_{j=1}^{n} \frac{R_{l j}}{(1+I R R)^{j}}-I_{t}=0 \\
\sum_{j=1}^{P b} \frac{R_{l j}}{(1+i)^{j}} \geq I_{t}
\end{gathered}
$$

Where $P b$ is the period of investment recovery. At the first stage the initial investment estimation is required, including the costs of floating structures, PV panels, inverters, cable connections, and electrical protections. According [23] the CAPEX values tacked into account are presented in table I, which are in line with the adjudicating cost of a similar power plant in Cuba-Alqueva, showed in Fig.6 that was around one million Euros. Therefore, it's a realistic value use $1000 € / \mathrm{kWp}$ for this kind of investment.

Table I. - CAPEX Direct Costs for a FSPV

\begin{tabular}{ll}
\hline Equipment & Value (USD/kWp) \\
\hline Panels & 300 \\
Inverters & 200 \\
Floating structure & 300 \\
Anchoring & 36 \\
Electrical equipment/devices & 100 \\
Installation \& Labour & 150 \\
Transport & 20 \\
\hline TOTAL & $\mathbf{1 1 0 6}$ \\
\hline
\end{tabular}

To account for the profits from the sale of the produced energy, the average reference tariffs practiced in 2020 were considered for the Price Of Energy (POE), which were around $40 € / \mathrm{MWh}$. This value reflects the average at the liberalized market of last six years, according OMIE (Iberian Electric Market Operator). Nevertheless, POE varies considerably every year, in this study, the $P O E$ was dynamic over the 25 years considered for the project lifetime, taking into account the inflation rate $(e)$ of $2 \% /$ year, calculated based on (17).

$$
P O E_{j}=P O E_{0}(1+e)^{j}
$$

Where $j$ represents the year for which the energy price is to be calculated. Another parameter to take into account to obtain the net cash flow is the annual Operation and Maintenance Costs $(O M C)$. As referred in [8], the $O M C$ varies with time and increases as the plant remains in operation, taking into account the inflation rate $(e)$ and can be approximated by (18).

$$
O M C_{j}=O M C_{1}(1+e)^{j-1}
$$

Where $O M C_{1}$ is the operation and maintenance cost in the first year. Table II presents a summary of the main parameters used in the techno-economic project evaluation.

Table II. - Parameters Used in the Techno-Economic Evaluation

\begin{tabular}{ll}
\hline Parameter & Value \\
\hline Project lifetime $(n)$ & 25 years \\
Yearly Energy/Electricity & $1800 \mathrm{MWh}$ \\
production & $6 \%$ \\
Discount rate $(i)$ & $1 \%$ of initial investment \\
O\&M yearly costs & $2 \%$ \\
Yearly inflation rate $(e)$ & $40 € / \mathrm{MWh}$ \\
Energy price in first year & $1000000 € / \mathrm{MW}$ \\
Initial investment costs & $15 \%$ of initial investment \\
Final Residual value $\left(V_{R}\right)$ & \\
\hline
\end{tabular}

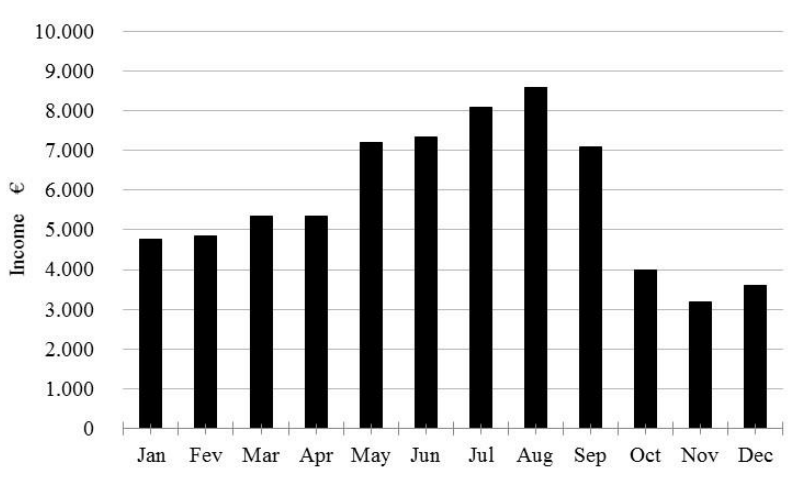

Fig.7. Monthly profits from energy sales for the first year.

Considering $P O E$ for the first year, the graph of Fig. 7 presents the cash incoming from the monthly energy sales, resulting in an amount around $72000 €$ for the first year. The return on an investment of approximately 1 million euros, will be evaluated taking into consideration, not only the financial return from the sale of the energy produced, which can be variable. As can be shown in Figure 8, if the energy is totally for sale, the investment will have payback period around 14 years, which is considered high, for renewable energy projects. However, the project presents a positive $N P V$ around $329235 €$ and a IRR about 5.8\%. Despite the high payback period time, these two indicators demonstrate the viability of this type of investment, which may improve in the near future with the expected reduction in technology costs. Another option, will be the use of the energy produced for self-consumption, allowing 
to feed the pumping stations of the hydro power plant. In this case, the financial return would be obtained from the savings side in the purchase of electricity which has substantially higher tariffs than the feed.in-tariffs considered.

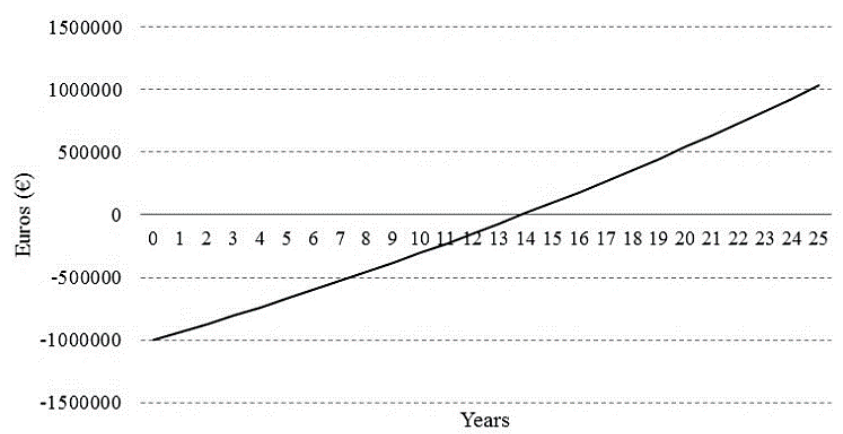

Fig.8. Amortization results over the project lifetime.

\section{Conclusion}

Southern European countries have interesting potential for installing FSPV, taking advantage of the solar resource and the large number of dams reservoirs. It proves to be an interesting solution, in the search for increased electricity production based on renewables, helping to meet the European goals imposed by the roadmap for carbon neutrality. Besides that, there are other advantages that this type of projects present, one of the biggest advantages is the fact that FSPV facilities do not require valuable land space inland. Another advantage is the increased efficiency in energy conversion. The water evaporation reduction is another interesting advantage too. While there are numerous advantages to floating PV, there are a main disadvantage to this technology: the costs. These plants require additional costs than more traditional types of PV installations. The case study carried out, demonstrate that the payback period to amortize the investment rounds 14 years, which remains very high for renewable investments. However, the results of the NPV and IRR demonstrate the potential that these systems can bring, bearing in mind that the trend is towards a reduction in investment costs, resulting from a reduction in the technology costs. Thus, while the investment costs do not decrease, its use is more suitable for supplying local and auxiliary systems, such as pumping stations, allowing a significant reduction in the energy bill.

\section{Acknowledgement}

This work is financed by National Funds through the Portuguese funding agency, FCT - Fundação para a Ciência e a Tecnologia, within project UIDB/50014/2020.

\section{References}

[1] Roadmap for carbon neutrality 2050, Long-term strategy for carbon neutrality of the portuguese economy by 2050, 2019.

[2] Alok Sahu, Neha Yadav, K. Sudhakar,"Floating photovoltaic power plant: A review",Renewable and Sustainable Energy Reviews, Volume 66,2016,Pages 815-824, 2016.

[3] Kim Trapani, Miguel Redón Santafé, "A review of floating photovoltaic installations: 2007-2013", Progress in Photovoltaics, Volume23, Issue4, Pages 524-532, April 2015.
[4] Parisa Ranjbaran, Hossein Yousefi, G.B. Gharehpetian and Fatemeh Razi Astaraei, A review on floating photovoltaic (FPV) power generation units, Renewable and Sustainable Energy Reviews.

[5] Luyao Liu, Qinxing Wang, Haiyang Lin, Hailong Li, Qie Sun, Ronald wennersten, "Power Generation Efficiency and Prospects of Floating Photovoltaic Systems", Energy Procedia, Volume 105, Pages 1136-1142., 2017.

[6] Sara Oliveira-Pinto and Jasper Stokkermans, Assessment of the potential of different floating solar technologies - Overview and analysis of different case studies, Energy Conversion and Management, 2020.

[7] N. Yadav, M. Gupta and K. Sudhakar, "Energy assessment of floating photovoltaic system," 2016 International Conference on Electrical Power and Energy Systems (ICEPES), Bhopal, pp. 264269, 2016.

[8] Goswami, A, Sadhu, P, Goswami, U, Sadhu, PK. Floating solar power plant for sustainable development: A techno - economic analysis. Environ Prog Sustainable Energy. Volume 38, Issue 6 2019

[9] Liu H, Krishna V, Lun Leung J, Reindl T, Zhao L. Field experience and performance analysis of floating PV technologies in the tropics. Progress in Photovoltaics, vol. 26, issue 12, pp 957-967, 2018.

[10] R. Cazzaniga, M. Cicu, M. Rosa-Clot, P. Rosa-Clot, G.M. Tina, C. Ventura, Floating photovoltaic plants: Performance analysis and design solutions, Renewable and Sustainable Energy Reviews, Volume 81, Part 2, Pages 1730-1741, 2018.

[11] Jian Dai, Chi Zhang, Han Vincent Lim, Kok Keng Ang, Xudong Qian, Johnny Liang Heng Wong, Sze Tiong Tan and Chien Looi Wang, Design and construction of floating modular photovoltaic system for water reservoirs, Energy, 2019.

[12] Kim S-H, Yoon S-J, Choi W. Design and Construction of 1 MW Class Floating PV Generation Structural System Using FRP Members. Energies; 10(8):1142, 2017.

[13] Abid, M., Abid, Z., Sagin, J. et al. Prospects of floating photovoltaic technology and its implementation in Central and South Asian Countries. Int. J. Environ. Sci. Technol. 16, pp. 1755-1762 (2019).

[14] J. Baptista and P. Vargas, "Portuguese national potential for floating photovoltaic systems: a case study," 2020 IEEE International Conference on Environment and Electrical Engineering and 2020 IEEE Industrial and Commercial Power Systems Europe (EEEIC / I\&CPS Europe), Madrid, Spain, 2020, pp. 1-5.

[15] World Bank Group, ESMAP, and SERIS. "Where Sun Meets Water: Floating Solar Market Report - Executive Summary." 131291. The World Bank., 2018.

[16] Farfan, Javier; Breyer, Christian; Combining Floating Solar Photovoltaic Power Plants and Hydropower Reservoirs: A Virtual Battery of Great Global Potential, Energy Procedia, Volume 155, 2018, Pages 403-411.

[17] Lu, Chen-Ruei Ku, Yuan-Hsiou Chang, Water quality improvement with artificial floating islands, Ecological Engineering, Volume 74, pp. 371-375, 2015.

[18] Agência Portuguesa do Ambiente, "Barragens em Portugal," 2019.

[19] PNEC-2030, "Portuguese main driver for renewable energy horizon 2030," 2019.

[20] Sobral, Márcio, Avaliação do potencial fotovoltaico flutuante em Portugal, MsC Thesis, University of Lisbon, Faculty of Sciences, Department of Geographical, Geophysical and Energy Engineering, 2018.

[21] JRC.EC.Europa, Online:https://re.jrc.ec.europa.eu/pvg_tools/en/tools.html\#PVP," 2020.

[22] Baptista, José; Morais, Raul; "Fundamentos de Energia Solar Fotovoltaica", Vila Real: UTAD (Série Didática, Ciências Aplicadas 383) ), ISBN 978-972-669-944-6. Edição do Núcleo Editorial e Gráfico dos SDB da UTAD, 2010

[23] Dizier, Antoine; "Techno-economic analysis of floating PV solar power plants using active cooling technique: A case study for Taiwan", Master of Science Thesis KTH School of Industrial Engineering and Management Energy Technology, STOCKHOLM, 2018. 